\title{
Brachiaria brizantha control by using fluazifop-p-butil on Tifton 85 pasture formation
}

\author{
Márcia Vitória Santos ${ }^{1}$, Francisco Affonso Ferreira², Francisco Cláudio Lopes de Freitas², \\ Dilermando Miranda da Fonseca ${ }^{1}$, Abner José de Carvalho ${ }^{2}$, Thiago Gomes dos Santos Braz ${ }^{1}$ \\ ${ }^{1}$ Departamento de Zootecnia - UFV. \\ 2 Departamento de Fitotecnia - UFV.
}

\begin{abstract}
This study was carried out with the aim of assessing the efficacy of the fluazifop-p-butyl herbicide to control Brachiaria brizantha, cultivar Marandu, in the formation of Tifton 85 grazing. Treatments consisted of five doses of fluazifopp-butyl herbicide $\left(0.0,62.5,125.0,187.5\right.$ and $250.0 \mathrm{~g} \mathrm{ha}^{-1}$ ) plus controls with no herbicide, in a completely randomized layout, with four replications. Each plot consisted of a 10-L capacity pot, with two B. brizantha plants and two Tifton 85 plants. The herbicide application was conducted before the tillage of $B$. brizantha, when they were about $15 \mathrm{~cm}$ high. Visual assessments of control of B. brizantha and intoxication of Tifton 85 plants, at 07, 21 and 45 days after application were carried out. Sixty days after application, plants were harvested at ground level and oven-dried. Regrowth was assessed in the same manner, 60 days after cutting, to determine their dry weight. Control of B. brizantha was noted to be above $50 \%$, from doses of $218.75 \mathrm{~g} \mathrm{ha}^{-1}$ at 45 days after application. The fluazifop-p-butylherbicide did not show to be efficient in the control of B. brizantha in the doses assessed and caused intoxication to Tifton 85 plants.
\end{abstract}

Key Words: chemical control, tolerance, weed

\section{Introduction}

The successful formation of pastures is, among other factors, related to the correct integrated management of weeds, since they compete with the grass, reducing production and forage quality, encouraging decreased support capacity and increased time of formation and recovery of pasture (Silva et al., 2002).

In areas of Cynodon spp (Tifton 85) cultivation, the occurrence of other species such as those of the genus Brachiaria is quite common. These are undesirable, due to their interference and multiplication, dominating the main forage in a short period of time (Santos et al., 2006, 2007, 2008).

The ability of Brachiaria species to survive adverse factors such as leafhoppers attack, long droughts, fire, and cultural practices aimed at their elimination, contributes significantly to the recognition that the Brachiaria plants are difficult to eradicate. The difficulty of eliminating Brachiaria has been considered to be due to factors such as: morphological characteristics of plants, which make them tolerant to some herbicide; the large amount of seed produced, which along with dormancy, facilitate the perpetuation of the species in the area; and the probable presence, in some species of Brachiaria, of allelopathic compounds that inhibit the growth of other grasses (Rodrigues \& Reis, 1994).
The chemical control of monocotyledonous weeds in pastures is not a simple task due to lack of selective grass herbicides for forage species, to soil seed bank, and to irregular germination, besides the high-capacity to the regrowth of some species (Pereira \& Campos, 2001).

The developmental stage of weeds interferes with the effectiveness of herbicides (Askew et al. 2000; Johnson \& Hoverstad, 2002). With respect to grasses, Smeda \& Putnam (1990) found that the effectiveness of fluazifop-p-butil was reduced when the number of leaves of grasses increased from 3.5 to 7. Thus, fluazifop-p-butil can provide greater control of B. brizantha when its application is conducted soon after plant emergence. However, further studies are needed to elucidate which dose is suitable for $B$. brizantha application, enabling the chemical control of this grass in pastures, as well as the tolerance of forages subjected to these molecules.

This study was proposed with the aim of assessing the effectiveness of fluazifop-p-butyl in controlling $B$. brizantha in the formation of Tifton 85 pastures.

\section{Material and Methods}

The experiment was conducted in unprotected environment on the campus of Universidade Federal de Viçosa-MG, located at $20^{\circ} 45^{\prime}$ south latitude, $46^{\circ} 51^{\prime}$ west 
longitude and 689 meters of altitude, from December 2004 to May 2005.

The test consisted of fluazifop-p-butyl herbicide applied in five doses: $0.0,62.5,125.0,187.5$ and $250.0 \mathrm{~g} \mathrm{ha}^{-1}$ plus controls (Tifton 85 and Brachiaria brizantha alone) without herbicide. The experimental layout was completely randomized with four replications.

The soil used was a clayey texture Oxisol (Latossolo Vermelho-Amarelo). The results of the chemical analysis of soil sampling, conducted in 0-20-cm layer were: $\mathrm{pH}$ in $\mathrm{H}_{2} \mathrm{O}$ : 5.43; P: 1.15 (Mehlich-1) and K: $53.00 \mathrm{mg} \mathrm{dm}^{-3} ; \mathrm{Ca}^{+2}: 1.50$; $\mathrm{Mg}^{+2}: 0.63$ and $\mathrm{Al}^{+3}: 0.50 \mathrm{cmolc} \mathrm{dm}^{-3}(\mathrm{KCl} 1 \mathrm{~mol} / \mathrm{L})$, CTC (T): $6.41 \mathrm{cmolc} \mathrm{dm}^{-3}$, sum of bases: $2.26 \mathrm{cmolc} \mathrm{dm}^{-3}$, sum of bases: $4.15 \mathrm{cmolc} \mathrm{dm}^{-3}$ and $2.65 \mathrm{dag} \mathrm{kg}^{-1}$ of organic matter and 20.35 of P-rem. Based on these results, limestone application was not performed. Once sieved, the soil was fertilized with $5 \mathrm{~kg}$ of single super phosphate per $\mathrm{m}^{3}$. Each plot consisted of a pot containing 10 liters of soil with two Brachiaria brizantha plants, cultivar Marandu, and two Tifton 85 plants. The pots were kept in unprotected environment.

The planting of Tifton 85 was conducted via vegetative propagation from seedlings in vegetative state, selected from the Agrostology Sector from the Department of Animal Science, UFV, in Viçosa. Each seedling was composed of a stolon with no leaves; they were $0.20 \mathrm{~m}$ long and had three gems. After selecting these in the field, three seedlings were transplanted per pot, adopting the same procedure for all pots. Brachiaria brizantha was sown in trays of polypropylene at a depth of $1 \mathrm{~cm}$, and transplanted 20 days after emergence, three seedlings per pot - approximately $5 \mathrm{~cm}$ in height, interspersed with Tifton 85 plants. After the settlement, thinning was held leaving two more vigorous plants of each species in each pot. After the planting the seedlings, both species were grown for 20 days for the application of herbicides. The weeds that occurred in experimental units were removed manually, so that the effect of treatment could be observed only in forager species. Every 14 days, fertilizations were done in coverage with $2 \mathrm{~g}$ of N-P-K (20-05-20) per pot. Irrigation was performed daily, keeping soil moisture at approximately $80 \%$ of field capacity.

At the time of application, the air temperature was $21^{\circ} \mathrm{C}$ with relative humidity of $72 \%$ and wind speed of $4.0 \mathrm{~km} \mathrm{~h}^{-1}$. It was applied with a backpack sprayer, equipped with a two flat fan nozzle bar ("range") XR11002, spaced at $0.5 \mathrm{~m}$, with constant pressure of $210 \mathrm{kPa}$, maintained by $\mathrm{CO}_{2}$, with equivalent spray volume of $\mathrm{L}$ to $180 \mathrm{ha}$. The application was conducted in late December and was performed when the $B$. brizantha plants were about $20 \mathrm{~cm}$ tall. The commercial product used was the Fusilade at a concentration of $250 \mathrm{~g} \mathrm{~L}^{-1}$ of fluazifop-p-butil.
Control assessment of $B$. brizantha plants and of Tifton 85 intoxication were at 07, 21 and 45 days after application (days after application), through visual observations, using a scale from 0 to 100 , where 0 (zero) is no control or intoxication, and 100 (one hundred) is full control of the species or death, respectively, for B. brizantha and Tifton 85.

At 60 days after application, the aerial part of plants of both species were cut at ground level, separated and dried in a forced ventilation oven at $65^{\circ} \mathrm{C}$ until constant weight to determine dry mass. After cutting the plants, the soil of the pots were irrigated and fertilized to provide optimum conditions for plant regrowth. At 60 days after cutting, plant ability to regrowth was assessed, and another cut and drying of the aerial parts of $B$. brizantha and Tifton 85 were performed following the same methodology adopted at 60 days after application.

After weighing, the dry matter of Tifton 85, harvested at 60 days after cutting was taken to the laboratory for the assessment of chemical composition. And it was subsequently ground in a "Willey" type knife mill, with 1-mm mesh and stored in glass containers. For laboratory testing ground samples were subjected to drying at $105^{\circ} \mathrm{C}$ for 24 hours.

The following were analyzed: crude protein (CP), neutral detergent fiber (NDF), acid detergent fiber (ADF), and in vitro digestibility of dry matter (IVDDM).

The $\mathrm{N}$ content in the samples for estimation of crude protein (CP), the levels of neutral detergent fiber (NDF) and acid detergent fiber (ADF) were determined according to Mertens (2002). The IVDDM was determined according to the method of Tilley \& Terry (1963), described by Silva \& Queiroz(2002).

The results were submitted to analysis of variance by $\mathrm{F}$ test at $5 \%$ probability. Subsequently, data of the control of $B$. brizantha and intoxication of Tifton 85 and dry matter production of forage species were subjected to regression analysis and in the choice of models, the biological explanation was considered, the $\mathrm{r}^{2}$ and the significance of parameters. The controls were compared with treatments submitted to herbicide using descriptive statistics for dry matter at 60 days after application and 60 days after cutting.

\section{Results and Discussion}

The action of fluazifop-p-butyl in the control of $B$. brizantha and in the intoxication of Tifton 85 was influenced by the doses used $(\mathrm{P}<0.05)$.

Fluazifop-p-butyl is an acetyl coenzyme A carboxylase (ACCase), and it is used for post-emergence control of 
annual and perennial grasses. Plants under the action of such product have lipid biosynthesis blocked (Konishi et al., 1996) and, thus, there is hindrance of root growth and of the aerial parts and altered pigmentation of leaves; these symptoms were observed in this study. Thereafter begins the necrotic process in the meristematic regions, which spreads throughout the plant (Thill \& Weller, 1995).

It was observed that the control of $B$. brizantha showed proportional relation to the dose applied, with maximum values of $57.26 \%, 84.38 \%$ and $71.64 \%$, observed at the highest fluazifop-p-butyl dose applied, at 07, 21 and 45 days after application, respectively (Figure 1).

The intoxication of Tifton 85 plants at the highest dose applied was $20.04 \%, 44.29 \%$ and $51.09 \%$ at 07,21 , and 45 days after application, respectively (Figure 2). These results indicate that $B$. brizantha showed greater sensitivity to fluazifop-p-butyl, when compared with Tifton 85 plants (Figures 1 and 2), in accordance with the studies of Santos et al. (2006, 2007 and 2008) who have reported increased tolerance of Tifton 85 to glyphosate. Smeda and Putnam (1990), and Friesen \& Wall (1991) also observed fluazifopp-butyl herbicide susceptibility differences between grass species. However, despite the greater tolerance, the efficient doses of fluazifop-p-butyl in controlling B. brizantha caused high toxicity in Tifton 85.

The intoxication of Tifton 85 plants with herbicides may be influenced by climatic factors and management. When Santos et al., (2010) assessed the tolerance of Tifton 85 to glyphosate in two different application periods, they elucidated that plants exposed to this herbicide in cooler periods of the year (winter) have lower tolerance when

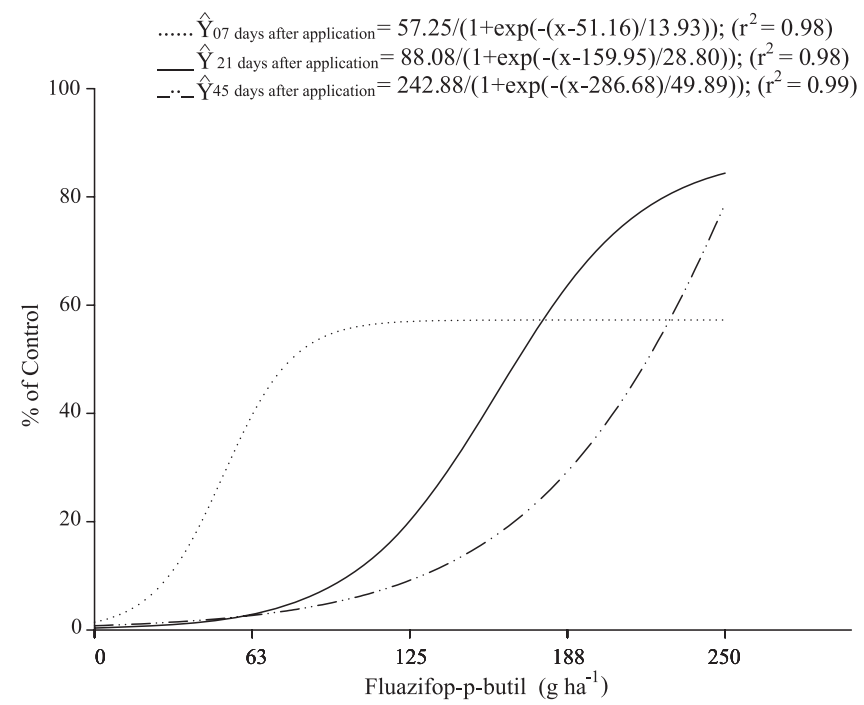

Figure 1 - Percentage of Brachiaria brizantha control for 07, 21 and 45 days after application, according to the doses of fluazifop-p-butyl.

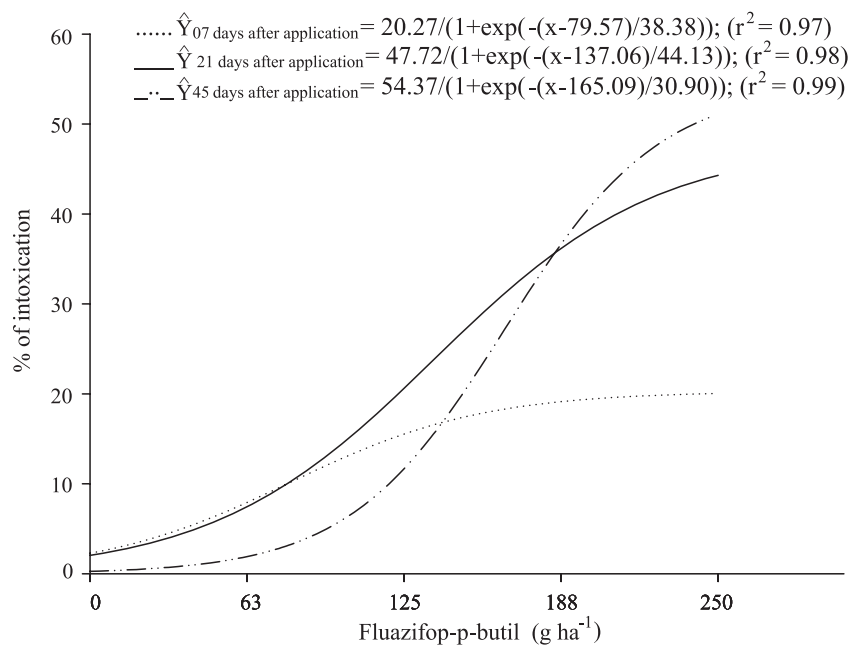

Figure 2 - Percentage of Cynodon spp. intoxication (Tifton 85) at 07,21 and 45 days after application, according to the doses of fluazifop-p-butyl.

compared with plants exposed to this herbicide in the summer. As reported by Santos et al. (2006, 2007, 2008), Tifton 85 plants, in the summer, tend to have greater tolerance to glyphosate, possibly due to favorable conditions for growth and development, such as temperature and rooting, which may be related to the ease of metabolism, conjugation and, or, exudation of herbicides by plants, in addition to further development of starchy rhizomes, serving as reserves for regrowth of plants.

The production of dry mass of $B$. brizantha and Tifton 85 was negatively affected by fluazifop-p-butyl, with marked reduction at 60 days after application for both species when applied at higher doses (Figure 3). This fact is possibly due to the low tolerance of $B$. brizantha and Tifton 85 to this herbicide. Moreover, it was noted that dry matter production of both species was reduced with crop in consortium in relation to controls, which had means of 172.2 and $32.8 \mathrm{~g} / \mathrm{pot}$ for Tifton 85 and B. brizantha, respectively. Such fact was due to competition between the forage plants.

At regrowth, 60 days after cutting, there was greater influence of fluazifop-p-butyl for Tifton 85, with drastic reduction in dry mass accumulated from dose of $187.5 \mathrm{~g} \mathrm{ha}^{-1}$, whereas for $B$. brizantha further damage was observed only in the applied dose of $250 \mathrm{~g} \mathrm{ha}^{-1}$ (Figure 4). The inefficient control of $B$. brizantha, did not prevent its regrowth, which further damaged the growth of Tifton 85 due to competition. Tifton 85, however, despite the higher initial tolerance to fluazifop-p-butyl, observed through a visual method, was more affected in regrowth. Regarding controls, the production of Tifton 85 dry mass ( $44.13 \mathrm{~g} /$ pot) in regrowth (60 days after cutting) is inferior to that of $B$. brizantha (62.57 g/pot) and similar to plots planted in consortium with 


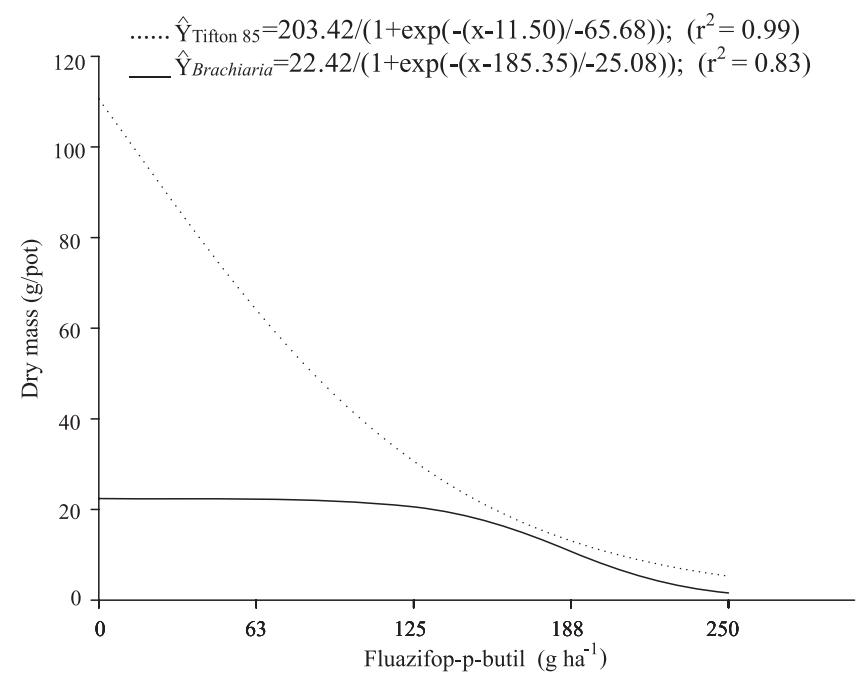

Figure 3 - Dry mass (g/pot) of Cynodon spp. (Tifton 85) and Brachiaria brizantha, subjected to doses of $0 ; 62.5$; 125; 187.5 and $250 \mathrm{~g} \mathrm{ha}^{-1}$ of fluazifop-p-butil, at 60 days after application.

no herbicide, which is possibly due to the slower growth of Tifton 85 after the cutting, plus the competition imposed by Brachiaria plants (Figure 4). The damage caused by fluazifop-p-butyl herbicide in the regrowth of Tifton 85 plants could compromise the establishment of forage grasses pasture and benefit the reinfestation by $B$. brizantha plants.

Smeda and Putnam (1990) reported that the grass species Setaria viridis, Digitaria sanguinalis, Setaria lutescens, Setaria faberi and Echinochloa crusgalli had different susceptibility to fluazifop-p-butyl, a fact also observed by Friesen \& Wall (1991) for Setaria viridis, Avena fatua, wheat, and barley. In this study, differences in tolerance to fluazifop-p-butyl in B. brizantha and Tifton 85 plants were observed, and the forage of Cynodon genus had increased susceptibility, which adversely affected the regrowth of plants at 60 days after cutting (Figure 4).

In a study on the competitive interaction of $B$. brizantha and B. plantaginea under reduced doses of fluazifop-pbutyl, applied in different periods (14, 24 and 34 days after plant emergence), Silva et al. (2005) concluded that $B$. plantaginea was more susceptible to fluazifop-p-butyl than $B$. brizantha, and that plants of both species subjected to $62.5 \mathrm{~g} \mathrm{ha}^{-1}$ of fluazifop-p-butyl were controlled. However, these authors did not study the effects of this herbicide in more advanced development stages of these grasses as well as the resilience of $B$. brizantha.

Fluazifop-p-butyl did not affect the chemical composition and in vitro digestibility of Tifton $85(\mathrm{P}<0.05)$ (Table 1$)$. This is possibly due to the short residual period of fluazifop-p-butyl

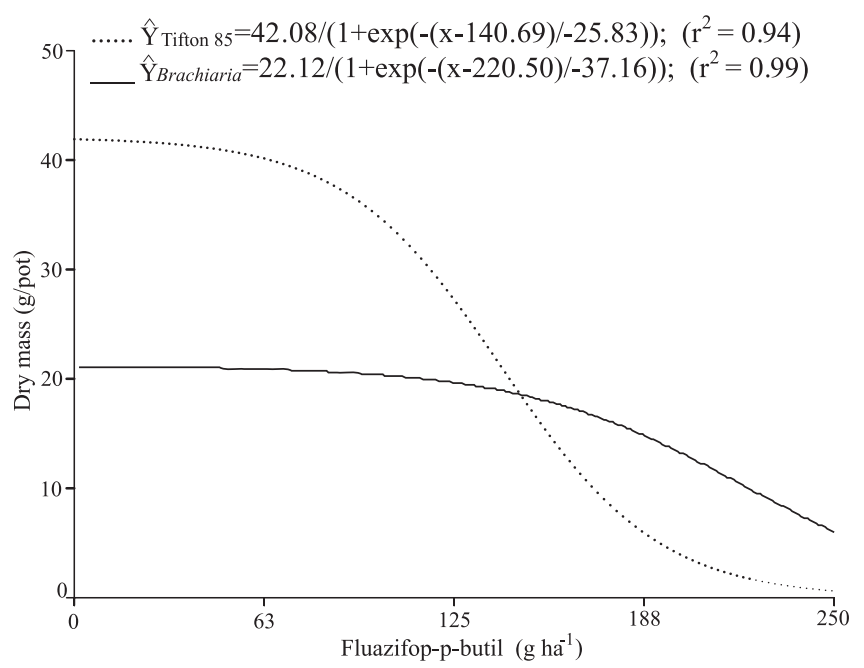

Figure 4 - Dry mass (g/pot) of Cynodon spp. (Tifton 85) and Brachiaria brizantha, subjected to doses of $0 ; 62.5$; $125 ; 187.5$ and $250 \mathrm{~g} \mathrm{ha}^{-1}$ of fluazifop-p-butil, at the 60 -day regrowth after the cutting.

in soil, which according to WSSA (1994), is 7 to 15 days, and does not influence the metabolism of plants.

The results of ADF, NDF, CP, and IVDDM of Tifton 85 (Table 1) are similar to those described in the literature for this grass species (Gonçalves et al., 2002; Moreira et al., 2006), which shows that although fluazifop-p-butyl compromises the regrowth of Tifton 85 plants, it does not influence the nutritional quality of this plant.

Table 1 - Chemical composition and in vitro digestibility of Cynodon spp. (Tifton 85) subjected to doses of 0; 62.5 ; 125 ; 187.5 and $250 \mathrm{~g} \mathrm{ha}^{-1}$ of fluazifop-p-butil, at the 60 -day regrowth after cutting

\begin{tabular}{cccccc}
\hline $\begin{array}{c}\text { Fluazifop-p-butil } \\
\text { doses }\left(\mathrm{g} \mathrm{ha} \text { h }^{-1}\right)\end{array}$ & ADF & NDF & CP & & IVDDM \\
\cline { 2 - 3 } & & $\mathrm{g} / \mathrm{kg}$ of DM & & g/g of DM \\
\hline 0.00 & 403.3 & $655.0 \mathrm{~ns}$ & 89 & & $0.599 \mathrm{~ns}$ \\
62.50 & 425.0 & $682.5 \mathrm{~ns}$ & 78 & & $0.610 \mathrm{~ns}$ \\
125 & 398.0 & $670.0 \mathrm{~ns}$ & 91 & & $0.605 \mathrm{~ns}$ \\
187.50 & 389.2 & $641.0 \mathrm{~ns}$ & 97 & & $0.614 \mathrm{~ns}$ \\
250 & 399.8 & $597.0 \mathrm{~ns}$ & 114 & & $0.632 \mathrm{~ns}$ \\
CV $(\%)$ & 9.6 & $6.7 \mathrm{~ns}$ & 4.7 & & $7.2 \mathrm{~ns}$ \\
\hline
\end{tabular}

CP - crude protein; NDF - neutral detergent fiber; ADF - acid detergent fiber, IVDDM - in vitro dry mass digestibility; ns - not significant at 5\% probability using $\mathrm{F}$ test.

\section{Conclusions}

Fluazifop-p-butil is not efficient in the control of B. brizantha plants; it is harmful to Tifton 85 when applied for the control of Brachiaria brizantha cv. Marandu, in the formation of Tifton 85 pastures. 


\section{References}

ASKEW, S.D.; SHAW, D.R.; STREET, J.E. Graminicide application timing influences red rice (Oryza sativa) control and seedhead reduction in soybean (Glycine max). Weed Technology, v.14, n.1, p.176-181, 2000.

FRIESEN, G.H.; WALL, D.A. Effect of application factors on efficacy on fluazifop-p-butyl in flax. Weed Technology, v.5, n.3, p.504-508, 1991.

GONÇALVES, G.D.; SANTOS, G.T.; CECATO, U. et al. Produção e valor nutritivo de gramíneas do gênero Cynodon em diferentes idades ao corte durante o ano. Acta Scientiarum, v.24, n.4, p.1163-1174, 2002.

JOHNSON, G.A.; HOVERSTAD, T.R. Effect of row spacing and herbicide application timing on weed control and grain yield in corn (Zea mays). Weed Technology, v.16, n.3, p.548-553, 2002 .

KONISHI, T.; SHINOHARA, K.; YAMADA, K. et al. Y. AcetylCoA carboxylase in higher plants: most plants other than gramineae have both the prokaryotic and the eucaryotic forms of this enzyme. Plant Cell Physiology, v.37, p.117-122, 1996.

MERTENS, D.R. Gravimetric determination of amylase-treated neutral detergent fiber in feeds with refluxing in beakers or crucibles: collaborative study. Journal of AOAC International, v.85, n.6, p.1217-1240, 2002.

MOREIRA, A.L.; REIS, R.A.; SIMILI, F.F. et al. Época de sobressemeadura de gramíneas anuais de inverno e de verão no capim-tifton 85: valor nutritivo. Ciência e Agrotecnologia, v.30, n.2, p.335-343, 2006.

PEREIRA, J.R.P.; CAMPOS, A.T. Controle da braquiária como invasora. Juiz de Fora, MG: Embrapa Gado de Leite, 2001. 2p. (Instrução Técnica para Produtor de Leite, 26).

RODRIGUES, L.R. de A.; REIS, R.A. Estabelecimento de outras forrageiras em áreas de Brachiaria spp. In: SIMPÓSIO SOBRE MANEJO DA PASTAGEM, 11., 1994, Piracicaba. Anais... Piracicaba: FEALQ, 1994. p.299-325.
SANTOS, M.V.; FERREIRA, F.A.; FREITAS, F.C.L. et al. Controle de Brachiaria brizantha com uso do glyphosate após o estabelecimento de Tifton 85 (Cynodon spp.). Planta Daninha, v.24, n.4, p.813-819, 2006.

SANTOS, M.V.; FERREIRA, F.A.; FREITAS, F.C.L. et al. Controle de Brachiaria brizantha, com uso do glyphosate, na formação de pastagem de Tifton 85 (Cynodon spp.). Planta Daninha, v.25, n.1, p.149-155, 2007.

SANTOS, M.V.; FERREIRA, F.A.; FREITAS, F.C.L. et al. Tolerância do Tifton 85 (Cynodon spp.) e da Brachiaria brizantha ao glyphosate. Planta Daninha, v.26, n.2, p.353-360, 2008.

SANTOS, M.V.; FREITAS, F.C.L.; FERREIRA, F.A. et al. Tolerância do Tifton 85 ao glyphosate em diferentes épocas de aplicação. Planta Daninha, v.28, n.1, p.31-137, 2010.

SILVA, A.A.; WERLANG, R.C.; FERREIRA, L.R. Controle de plantas daninhas em pastagens. In: SIMPÓSIO SOBRE MANEJO ESTRATÉGICO DA PASTAGEM - SIMFOR, 2002, Viçosa, MG. Anais... Viçosa, MG: Editora Suprema Gráfica LTDA, 2002. p.279-310.

SILVA, A.C.; FREITAS, R.S.; FERREIRA, L.R. et al. Interação competitiva de Brachiaria brizantha e B. plantaginea sob doses reduzidas de fluazifop-p-butil, aplicadas em diferentes épocas. Planta Daninha, v.23, n.1, p.79-84, 2005.

SILVA, D.J.; QUEIROZ, A.C. Análise de alimentos: métodos químicos e biológicos. 3.ed. Viçosa, MG: Editora Universidade Federal de Viçosa, 2002. 235p.

SMEDA, R.J.; PUTNAM, A.R. Influence of temperature, rainfall, grass species, and growth stage on efficacy of fluazifop-p-butil. Weed Technology, v.4, n.2, p.349-355, 1990.

TILLEY, J.M.A.; TERRY, R.A. A twostage technique for the in vitro digestion of forage crops. Journal of the British and Grasslands Society, v.18, n.1, p.104-111, 1963.

THILL, D.C.; WELLER, S.C. Lipid biosyntesis inhibitors. In: Herbicide action course. Wes Lafayetty: Purdue University West Lafayette, Indiana, 1995. 787p.

WEED SCIENCE SOCIETY OF AMERICA - WSSA. Herbicide handbook. Champaign, Illinois: Weed Society of America, 1994. 352p. 